\title{
Understanding Mathematics Contents as a way to Change Pedagogical Activities of Preservice Teachers
}

\section{Mudança na Atividade Pedagógica de Professores de Matemática em Formação Inicial a partir da Compreensão do Conteúdo}

\author{
ID Maria Marta da Silva ${ }^{1}$ \\ Wellington Lima Cedro² \\ 'Universidade Estadual de Goiás (UEG), Campus Sudoeste, Quirinópolis, GO, Brasil. \\ ${ }^{2}$ Universidade Federal de Goiás (UFG), Instituto de Matemática e Estatística, Goiânia, GO, Brasil. \\ Autor correspondente: wcedro@ufg.br
}

\begin{abstract}
This article aims to investigate the changes occurred in the pedagogical activity of preservice Mathematics teachers as they understand the Mathematics content as one of the elements composing their activity. The research methodology used was of a formative experiment. The sample comprised ten preservice teachers. Among the recorded results, it is important to highlight the awareness that contents must be seen as a set of scientific knowledge about a given discipline, in our case, Mathematics. These contents are socially and historically constituted; they must be the product of human social and historical experiences, which are essential for individuals' development during teachers' pedagogical activities.
\end{abstract}

Keywords: Teacher training; Mathematics teaching; Contextualization of content; Pedagogical activities.

Resumo: Esse artigo tem como objetivo investigar as mudanças causadas na atividade pedagógica de professores de Matemática em formação inicial ao compreenderem o conteúdo matemático como um dos elementos que constituem a sua atividade. Os sujeitos de pesquisa foram dez professores que durante o processo participaram de um experimento formativo que teve a duração de um ano letivo. Dentre os resultados destacamos a compreensão de que os conteúdos devem ser vistos como conjuntos de conhecimentos científicos de uma disciplina, em nosso caso da Matemática e, que são constituídos social e historicamente, objetivando-se como produtos da experiência social e histórica humana, considerados essenciais para a promoção do desenvolvimento do sujeito durante a atividade pedagógica do professor.

Palavras-Chave: Formação inicial do professor; Ensino de matemática. Contextualização do conteúdo; Atividades pedagógicas.

Recebido em: 21/01/2020

Aprovado em: 20/10/2020 


\section{Introduction}

According to D'Ambrósio (2007) and Lorenzato (2010), among others, math teacher training needs to be guided by the articulation between elements that make up the pedagogical activity of the teacher. Such articulation must allow planning and evaluation to be a fruitful connection between student and content.

Moura et al. (2016) show the need of integrating elements such as planning, content and evaluation. The ones in charge to train future teachers must work hard to develop such a relation, so that teachers will be able to teach specific contents in an organized way. In order to reach such integration, i.e., knowledge about specific contents and about how to organize their teaching, the set of courses in Mathematics teacher training programs in Brazil focuses on specific Mathematics contents and didactic and pedagogical formation - separately. Thus, researchers are working on investigating Mathematics teachers' education in order to reach theoretical common ground to meet today's educational demands (LIBÂNEO, 2008; MOURA et al., 2016; PIMENTA; LIMA, 2017).

The present article complies with the scenario set by these discussions and aims to understand what changes occurred in the pedagogical activities of preservice Mathematics teachers who realize that the Mathematics content are one of the elements composing such particular activity. Our sample comprised ten teachers who participated in a training program for one school year. The experiment was conducted by the professor in charge of the discipline named Supervised Internship. In this period, we tried to find the answers to the following question: What actions have demonstrated changes in the pedagogical activity of undergraduate Mathematics teachers during the experimental period in terms of understanding that the Mathematics content is one of the elements composing such activity?

We first present a discussion about the Mathematics teacher education as well as information on the method and methodology used in the study. Next, we describe the data analysis, which lied on a perspective that goes beyond a simple description in order to better explain the problem addressed in the research. Finally, we bring some considerations on the teacher education process experienced by Mathematics teachers and the evidences about their awareness of contents as one of the elements determining the development of their pedagogical activity and of students' learning process.

\section{Preservice Mathematics Teacher Education}

Preservice Mathematics teacher education is a vast subject for research, as it poses challenges that embody different forms in space and time, within distinct historical-social contexts. According to Pimenta and Lima (2017) and Moura et al.(2016), it is essential to discuss Mathematics teachers' education, careers and weaknesses, as well as their organization and transformation skills.

With respect to courses available for Mathematics teachers in Brazil, the study by Gatti and Nunes (2009) used a sample with 31 disciplines focused on the features and composition of school curricula and respective amendments. Results have shown growth in availability of teacher training programs focused on Mathematics teacher's 
education in private institutions between 2001 and 2006, as well as a larger number of students enrolled in these programs. On the other hand, the number of students in the same courses in public institutions has decreased, which suggest that students from public schools who seek teacher licensure look for attending private universities.

Nonetheless, Gatti and Nunes (2009) observed a strong emphasis on specific, rather than methodological, knowledge when assessing 1,228 mandatory and 100 elective courses. When it comes to Supervised Internship, these authors found that "[...] credit hour requirements and supervised internship processes remain unclear" (GATTI; NUNES, 2009, p. 107, our translation). The study did not detect any intentionally organized project to connect formation aspects to Mathematics teaching.

Similar to these results, the present study also found two models of Mathematics licensure programs in Brazil: the ones focused on a basic formation in Mathematics, which opens up space for pedagogical formation, geared towards the Education field and courses on the teaching of Mathematics; and those based on courses focused on specific formation in Mathematics in order to meet the Curriculum Guidelines for Mathematics Courses - these programs provide only few courses addressing Education or Mathematics Teaching.

Researchers such as D'Ambrósio (2007), Fiorentini (2009), Libâneo (2004), and Moura et al. (2016), among others, have been publishing studies about Mathematics teachers' education in Brazilian universities. Publications resulting from their research have been heating discussions on the education of these teachers. The goal is to better understand the elements composing their pedagogical activity and how these elements interact with each other. These researchers point out that part of problems concerning Mathematics teaching relates to the process of preservice teacher education. They did so in order to address the interdependence between aspects composing Mathematics teachers' pedagogical activity, such as planning, content and evaluation. They start from the premise that Mathematics teacher education is supported by content reproduction, which does not change the objective reality nor contributes to create a new reality; instead, it just quantitatively multiplies previously produced qualitative changes.

As opposed to the aforementioned concepts and in order to better understand the Mathematics teacher education process, authors like Cedro (2008), Lanner de Moura (2007), Moraes (2008), Moura et al. (2016), Silva (2018), among others, assumed that the theoretical-methodological assumptions of the cultural-historical approach and its association with dialectical and historical materialism could provide a strong ground in this sense. These authors understand Mathematics Teacher education as "[...] the necessary mediation in the process of constitution of the individuals involved, rather than just an end in itself" (MOURA, 2000, p. 89, our translation).

Therefore, embracing the cultural-historical approach as the basis to think the Mathematics teacher education process means "[...] to understand it as a means of appropriating the historically produced culture" (MORAES, 2008, p. 112, our translation). More than that, it means to see such education as a central process to the formation of teachers as agents with their own historical specificities (LANNER DE MOURA, 2007). Thus, it would be possible to attain a Mathematics teacher education that derives from interactions set within their fields of action, which should be taken into consideration when teaching Mathematics contents (MOURA et al., 2016). The teaching of Mathematics content must consider the fact that knowledge appropriation is different for each 
individual. According to Silva (2018), knowledge results from teachers and students' social practices, it derives from the dialectic relationship in which theory guides the practice, and practice changes the theory. This process paves the way for knowledge production at different levels, based on students' understanding.

According to the aforementioned premises and in order to understand the role of content as elements of Mathematics teachers' pedagogical activity, the chosen research method and methodology will be presented. They cover the process taken to develop the awareness of contents as an aspect composing Mathematics teachers' pedagogical activity.

\section{The Importance of Contents to Individuals' Development}

The purpose of making students advance in their development relates to the basic premise of pedagogical activities, namely: learning. The historical-cultural awareness regarding intellectual development process is mainly concerned with the role of the content and the relations that individuals make with it.

Vigotski (1995) shows that intellectual development derives from the relations that individuals make with the content; in other words, content appropriation by the individual leads to the development of their psychological functions. Therefore, teachers must address a content capable of making students progress through the pedagogical activity, that is, students should not be taught information that they already know about or topics that are beyond their current abilities. Such concept about the choice for a certain content is one of the elements to guide teachers' decision about what to teach. By selecting a content, teachers challenge the individual/content relationship, which is herein understood as the individual/object relationship. Radford (2011, p. 13, our translation) states that mathematical objects must not "[...] be acknowledged only as existing entities, but as conceptual objects generated by human activities".

In this way, the meaning given to this relationship comes from the expectation about what is to be produced, the expected intellectual development and the understanding about how to achieve what is needed. Thus, teaching content should imply a different student every time; therefore, the purpose of offering a content must be systematically assessed, as achieving intellectual and social development changes in every single occasion and opens new possibilities for the pedagogical activity. The interconnection between individual and content from the teachers' perspective emerges and consolidates after teachers acknowledge each student as a unique individual. This teacher-individual faces the complex task of organizing their pedagogical activity by taking into account the heterogeneity of students in the classroom and the individual trajectories of content appropriation to be taught to the student-individual.

Given the theoretical assumptions of our investigation, we assume a complex association between language and thought, in which it is a fact that school contents play a role in strengthening the act of thinking, in a way to unleash individuals from the shackles of empiricism. Therefore, the formative process developed that gave rise to this article includes the issue of teaching knowledge in the form of content, so we question how to think about the teaching process of school mathematical content taking such theoretical considerations into account, as well as how to relate the dialectical movement with this same content. 
In the face of such questions, we also stress the need to allow students to study these contents as historically produced and systematized knowledge, in a way that they can also understand the social practice of school content to be used to transform reality.

According to Vigotski (2004), school enables the generation of a learning process that consists of appropriation of contents found in the school's social-cultural space. The author also points out that development would be the inner reconstitution, at intrapsychic level, of what was learnt from these contents. That way, the pedagogical activity aims at overcoming the content known by the student in order to introduce another one, as doing so would take such knowledge to a higher level.

According to Libâneo (2008), these conceptions pose essential aspects for a teaching of contents that promotes intellectual development. However, for such contents to actually work as development agents, teacher's actions should take into account more than just information about current events from the different aspects of culture or simple appropriation of techniques for immediate application. It is demanding to redeem the historical processes to elaborate such acquisitions. The analysis of the very essence of the social-historical knowledge is fundamental for students to appropriate material and ideal elaborations. According to Radford (2011, p. 44, our translation), it would be "[...] a matter of better understanding the nature of mathematical knowledge and finding new teaching possibilities within its historical structure". It is worth mentioning that such elaborations are vital to overcome empirical and spontaneous conditions caused by the contemporary capitalist sociality, observed in the relations between individuals and society, which are fragmented due to an alienation process.

Thus, the selection and identification of mathematics contents to be taught at school and the definition of the appropriate conditions to materialize the actions are the way to organize the teaching process, which requires teachers to fathom the importance of this move within the teaching/learning relation. In order to understand the human thoughts that gave birth to mathematical contents and their rise and development, it is necessary to establish their relation with the cultural context (RADFORD, 2011). This association is observed as a formative experiment, so study tasks were planned, as presented below.

\section{Method and Methodology: interconnected pathways supported by the same theoretical basis}

Based on our theoretical perspectives and in a way to find the truth about the investigated phenomenon, we planned and developed a formative experiment with ten teachers in training during an academic year. The experiment comprised 36 meetings that took place during supervised internship classes in the university and 32 meetings to develop school-field internship activities (developed in 2013). According to Davydov and Markova (1987, p. 326, our translation), the formative experiment "[...] is a structure to investigate the development of human psyche, which dwell on studies by Vigotski". Vigotski (2003, p. 86, our translation) stated that only experimental analyses would allow "[...] understanding the process through which the concept formation evolves in real human life". 
In order to ease the understanding about the structure and development of the formative experiment, Chart 1 depicts the moments composing it.

Chart 1 - Formative Experiment Moments

\begin{tabular}{|c|c|c|c|}
\hline $\begin{array}{l}1^{\text {st }} \text { Moment: Theoretical } \\
\text { references }\end{array}$ & $\begin{array}{c}2^{\text {nd }} \text { Moment: Planning the } \\
\text { teaching tasks }\end{array}$ & $\begin{array}{l}3^{\text {rd }} \text { Moment: } \\
\text { Re-elaborating the } \\
\text { teaching tasks }\end{array}$ & $\begin{array}{l}4^{\text {th }} \text { Moment: Analysis } \\
\text { about the new synthesis }\end{array}$ \\
\hline $\begin{array}{l}\text { Planned to expose the } \\
\text { chosen theoretical basis. } \\
\text { For this, we studied texts } \\
\text { by the main authors that } \\
\text { substantiate the organization } \\
\text { of study tasks. The aim was } \\
\text { to provide cognitive means } \\
\text { to understand and change } \\
\text { the objective reality. }\end{array}$ & $\begin{array}{l}\text { We planned two sets of } \\
\text { tasks: one about interest } \\
\text { and another about areas } \\
\text { of plane figures. Such } \\
\text { tasks were theoretically } \\
\text { and methodologically } \\
\text { substantiated by the } \\
\text { Teaching Guidance Activities. }\end{array}$ & $\begin{array}{l}\text { Featured as the space } \\
\text { available for future teachers } \\
\text { to re-elaborate study tasks. } \\
\text { This happened in parallel } \\
\text { to the development of such } \\
\text { tasks in the school-field } \\
\text { internship. }\end{array}$ & $\begin{array}{l}\text { At this moment, teachers } \\
\text { socialized the experienced } \\
\text { situations. The goal was to } \\
\text { understand the process to } \\
\text { use contents as elements of } \\
\text { pedagogical activities. }\end{array}$ \\
\hline
\end{tabular}

Source: elaborated by the authors.

In order to get to know and understand the phenomenon in process, all the development of the formative experiment was recorded in digital audio-visual format. These recordings were fully transcribed and became the database for this study. These data will be further analyzed to achieve the study aims.

In the next session, we present the structure of our analysis which aims at covering the actions of a group of undergraduate Mathematics teachers who understood the use of contents as elements of their pedagogical activity during the elaboration of tasks to be practiced throughout their supervised internship. Such peculiarities, their episodes, scenes and flashes will be highlighted in the analysis unit, as follows.

\section{Data Analysis Beyond Description: explaining the research problem}

Data analysis demands acknowledging that this process does not lie on theoretical-methodological guidance. Therefore, it becomes indispensable to bear in mind the importance of a method to ground the production of knowledge derived from this process itself. Thus, we highlight that the method chosen and applied refers to all stages of the present study, rather than just to the data analysis - it is the socalled dialectical historical materialism. Therefore, the present analysis is not limited to a simple description, but encompasses an explanation, leading to the concretization of the phenomenon (KOSIK, 1969).

Following this logic, based on the collected data, the unity was defined, based on Vigotski (2001, p. 19, our translation), as "[...] a living and indivisible part of the whole". This allowed to selecting teaching episodes that can be understood as actions that disclose the education process (MOURA et al., 2016). Hence, the teaching episode was divided into two scenes in order to better understand the constituted phenomenon. According to Moura et al. (2016), these scenes are composed of moments when individuals confirm indications about the use of established formative actions. In these scenes, some flashes represent traces of change in individuals' thinking (SILVA, 2018). These are not "[...] a mere definition of signs, but an attempt to find in its web more than just the existence, but also the very nature of the signifying process of the involved individuals" (SILVA, 2018, p. 89, our translation). The flashes also make it 
possible "[...] to bond little details and peculiar indications, i.e., they link the particular to the universal, they become a peculiar way to understand data from the analysis of episodes and scenes composing them" (SILVA, 2018, p. 152, our translation). Therefore, our aim is to understand, based on the analysis process, how individuals became aware of the content as an element constituting their activity during the development of supervised internship actions. The chart below shows how this analysis was organized in order to explain this move.

Chart 2 - Description of movements observed inside the Analysis Unit

\begin{tabular}{|c|c|}
\hline \multicolumn{2}{|c|}{$\begin{array}{l}\text { Analysis unit: Understanding the role of contents to the elaboration of Mathematics teachers' } \\
\text { pedagogical activities }\end{array}$} \\
\hline \multirow{2}{*}{$\begin{array}{l}\text { Episode: Interdependence } \\
\text { between aspects linked to the } \\
\text { pedagogical activity }\end{array}$} & \\
\hline & $\begin{array}{l}\text { cene 2: The importance of the didactic pro } \\
\text { neeting between student and the content tc }\end{array}$ \\
\hline
\end{tabular}

Source: Elaborated by the authors.

\section{Episode: Interdependence between aspects that ground the pedagogical activity}

This episode, the scenes composing it and their flashes, are the way to understand how the associations between individuals in the research become real. This analysis evidenced the potential and range of the ascension movement from abstract to concrete, which was proposed in the present investigation. It was the means to understand the previously observed formative reality by guiding an in-depth understanding about the relationships addressed with more detailed elaboration. This movement also enabled elucidation and discernment between objective phenomena found in the actions by the investigated individuals or, in other words, the several dimensions and aspects constituting the relationships between individuals.

\section{Scene I - the role of the content in the establishment of the pedagogical activity}

Location and scenario to assure scene I - The scene took place in the tenth meeting of the formative experiment, during an internship class in the university. The scenario set for this scene was around the discussions that had preceded the choice for the content to be used in the first activities.

1: Aline: Guys, Tiago was right, we have to choose the content.

2: Vanusa: We don't have many options... we must choose contents about finances, otherwise we won't meet the required curriculum guidelines.

3 (1): Vivian: We can't start from something too hard... we have to start from something close to what they already know.

4: Tiago: Are you talking about teaching something they already know?

5 (2): Vivian: No, I'm talking about choosing something related to mathematical finance, something they don't know yet, but that is close to something they already know, then we add the information they don't know.

6: Vanusa: Look, I work at a car dealership, if there is one thing people who leave school don't know, it's to deal with interest rates.

7: Aline: What do you think if we choose interest as the content?

8: Luciana: Ok. It's fine for me. 
9: MM: What do you think?

10: Bruna: So be it.

11 (3): Yann: And what if we could use the historical synthesis to plan the activity to them, because then we will find the ups and downs that led to the concept of interest we have today.

12: Joel: It'll be good because they will understand how much they pay for a financed car.

13: Marilene: So guys, choosing this content will be very important for students at school because it fits the reality they observe at home.

14: Vanusa: You know what? Almost no one who buys cars in my shop mention anything about interest rates, actually, they don't even ask to see how we calculate it.

15: Marilene: They don't ask because they have no idea on how to calculate it.

16: Joel: [...] or they don't even want to know.

17: Aline: Maybe, if they had at least a slightest idea about it, they would ask.

18: Bruna: That's true.

19 (4): Gabriela: What if after our class the students change their opinion about interest?

20: Vanusa: That's true Vivian, I hope it happens for real, it would be awesome.

21: Luciana: I hope it does.

22: Tiago: So, let's plan it.

23 (5): Marilene: Choosing this content will be important because it matches their reality, it's something they already know, but that they actually didn't know how to do, and our role is to guide their learning about it.

24: Bruna: Also as interest will be the content and as it matches their reality, then what do you think about using a daily situation to trigger the Learning Process?

25: Tiago: I agree with it, I guess that it will be cool because interest rates give the opportunity to work with a task.

It is important to note that thoughts are elaborated and developed with generalization, i.e., it goes from individual to general then back to individual again. Generalization is the act that connects thought and language. The individual learns the generalizing function of thinking at school through the mediation of the theoreticalscientific language. It is different from what is observed in the daily language for social communication. Given the theoretical assumptions in the present investigation, it was possible to take into account the complex association between language and thinking. The role of the content is also acknowledged, since it reinforces the act of thinking and unleashes it from the empirical ties. This scene aims at the issue about turning knowledge into content. This process is a way to allow students to go from spontaneous to a more elaborated knowledge (scientific).

Vivian (Flash 1) and Tiago (Flash 2) show that they had understood the important association between learning process and development, referred by Vigotski (2003) as the dialectic relationship that, although not limited to school environment, is as important as the role it plays, mainly when it comes to teachers' understanding about the need of establishing the way the individual must act within the so-called proximal development zone of their students. It is done in order to allow them to make their potential development real. Flashes that corroborate such discussion are presented below.

With respect to this development zone, Vigotski (1995) establishes the existence of two development levels. The first, named real development level, concerns actions that individuals take on their own, in an independent way. The second one, known as potential development, regards what this individual is able to achieve with the help of adults. The speech by Vivian (Flash 2) highlights that the route to be taken by the student between the potential and real zones is the same route the teacher must take, and this trajectory must encourage inner conquests of the individual towards learning. "[...] the essential feature of learning encompasses the potential development field, 
i.e., it encourages a set of inner inter-relation processes that promote the individual's development" (VIGOTSKI, 2003, p. 115, our translation).

In regards to the association between learning and development, this author also points out that a good teaching is the one acting in students' proximal development zone. Accordingly, it is convenient to ask: how can one think about the process to teach a certain Mathematics content by taking into account such theoretical considerations? How is it possible to establish specific teaching and learning actions for Mathematics contents?

The answer to such question points towards teachers' concern with clarifying the scientific dimension of the content to be taught. In other words, they want students to learn this content as historically produced and as a systematized knowledge; this statement is clear in Yann's speech (Flash 3).

These confrontations are seen by the individuals in the research as the social practice of the discipline content to be used in the process to change students' reality - this process is evident in the speech by Gabriela (Flash 4). After being aware of content as an important element of the pedagogical activity, it is possible to observe the effort by the undergraduate teachers to articulate the practice-theory-practice move that had started at students' current development level.

Teachers want to move from the immediate development zone to provide a new development level for students. In such process, developing upper psychological functions becomes possible. Such development is mediated by appropriation of content by the students at school, which is made up of the articulation between language and thought. Besides, it can generate learning.

According to Vigotski (2004), learning means using the contents found in the school, which is a social-cultural environment. Development, in its turn, concerns the inner reconstruction, at an intra-psychological level, of what was learnt from such contents. Marilene (Flash 5) highlights that the addition of a new content about the subject to be taught, as stated by Vigotski (2004), shows that the teacher is in charge of focusing its guiding actions on what students do not know yet, but the new content must start from what students already know.

These concepts point out essential aspects for the process of learning a content and promoting students' development. However, in order to turn these contents into agents of development, it is necessary that teachers' actions take into account information that represents current events based on different aspects of culture or the use of techniques for immediate use. It is essential to redeem historical processes for the elaboration of such acquisitions, as it can be observed in the speech by Yann (Flash 3). So, it is fundamental to analyze the very essence of the socio-historical knowledge, so that students can appropriate material and ideal elaborations. Therefore, selecting and identifying the content to be taught at school, as well as defining the appropriate conditions to materialize the teaching actions in the pedagogical activity forces teachers to understand the importance of movements in the teaching and learning processes.

Based on this movement of assimilation of the value of the content as an element of Mathematics teachers' pedagogical activity, teachers follow the process of enlightening and criticizing their personal and collective elaborations throughout the formative experiment, which they are part of. They also realized other relevant matter: 
the importance of the didactic process as the way to have a formative encounter between the student and the content to be taught. This process is shown by the activities conducted by the undergraduates themselves. Thus, this is the way to enable the amplification of their ability to think according to the analysis and synthesis process applied to individual and collective actions based on the rise of new synthesis about the complex composition of the pedagogical activity. These questions are discussed in the scene described below.

\section{Scene 2 - The importance of the pedagogical process: the formative meeting between the student and the content to be taught}

Location and scenario for the effectiveness of Scene 2 - This scene was observed in the twentieth meeting of the formative experiment, during internship in the University. The scenario is composed of discussions that took place during the activity to choose a content from the plane figures field.

1: Tiago: During my vacation I looked at the list of contents and I thought about what we are going to do.

2: Joel: So do I.

3: Vanusa: Me too.

4: Vivian: So today we'll choose the content.

5 (1): Gabriela: The biggest problem is that it's not just choosing the content, but that we have to find out how to organize the teaching process, and I think that part of this problem relates to the graduation program, as we didn't have enough classes on didactics, but instead on how to teach the Mathematics content.

6: Yann: Do you feel better now, Gabriela?

7: Gabriela: It is not about feeling better, but telling the truth.

8: Vanusa: Gabriela is right, in order to change issues linked to teaching of Mathematics contents there should be a change here in the University first.

9 (2): Luciana: Here in the university what we mostly see is the teaching of Mathematics content in the most traditional way possible, like, the follow-the-example type. Contents are important, the school makes no sense without them but the way we teach has to change. It seems that, mainly in public schools, they want student to go to school so that we can babysit them.

10: Bruna: That's true.

11: Joel: If we are going to teach geometry, so let's do it differently.

12: Gabriela: Talking about content, in my opinion, the primary goal of the school is to teach content, and this is something private schools do well.

13: Vanusa: You know that because you studied in a private school.

14: Joel: Yep, there is a huge difference.

15: Tiago: We basically don't teach geometry in public schools.

16: Bruna: So now, it is our turn to give our contribution to these students.

17: Joel: Let me ask you something: when you say that here in our course we do not have classes on didactics, I got a little lost, what were you talking about?

18: Bruna: I guess it was Gabriela who mentioned that.

19: Vivian: Yes, that's right.

20 (3): Marilene: When she mentions that we don't have the didactics to teach Mathematics contents, she is referring to the fact that our program doesn't express concern about courses to allow studying how to enable a real encounter between the student and Mathematics content.

21 (4): Tiago: Teacher education don't value didactics, so it seems that the student does not meet the content, as Marilene said.

22: Bruna: The problem is that the program does not have much time to discuss the reality of the schools.

23: Luciana: They teach us the hard contents but forget the contents we have to teach at basic education.

24: Vanusa: That's true.

25: Luciana: We had a hard time turning percentages into decimal numbers.

26 (5): Aline: It happens due to the same reason why students do not learn the Mathematics contents: there is a gap between teaching and learning, here in the university I sense, by the view of our professors, that teaching and learning are two different things. I am not saying that teaching a content and learning it are the same thing, but that there is a strong link between them. 
27: Marilene: It is a huge challenge.

28: Bruna: Right?

29: Gabriela: But we have to try.

30: Tiago: There's so much concern with the content we'll teach and how we're going to do it, but the school, especially those public, as well as students and parents do not care about what they're learning. They just care if the child is at school.

31: Joel: And when they learn a content it seems that it'd just sprouted from the ground, that it didn't come from somewhere.

32: Vanusa: But it also happens here, for example, Mathematics contents are taught in a disconnected way from Mathematics itself. Let's be honest, we just realized such a relations when we got to know the theory, when we needed to make the historical synthesis before a task.

33: Marilene: Just now, almost at the end of our graduation course, we were introduced to a specific methodology to teach Mathematics.

34: (6) Vivian: You know what? I think that it is not just the internship that was wrong, it is almost the entire way our course is organized, because when we talk about little or no didactics to teach Mathematics contents, I believe we didn't have anything on didactics at all, because only now we understand a little about it, what is didactic for, and we ended up finding out that a discipline that was not taught throughout the course is so important, it could have helped us to understand that there is no learning without teaching, therefore, we would have understood why the theory has this name, because it guides the teaching process, because teaching has to be guided, and such guidance is learning.

35: Joel: So, if now we are guided by the teaching guiding activity and by the professor, let's choose a content and get to work.

36: Vanusa: That's true.

37 (7): Yann: The good thing about it guys is that we are learning contents taught at basic education, because here they just worry about hard contents such as Calculus and then we are in charge of the basic contents for the internship. At least at this time things are working out just fine, because equations, interest calculations and geometry are basic education contents.

Graduation institutions and Brazilian basic education schools are facing new demands about how to teach Mathematics contents (D'AMBRÓSIO, 2007; FIORENTINI, 2009; LIBÂNEO, 2004; MOURA et al., 2016). These studies point out the need of individuals to learn such contents. The perception about this issue is highlighted in the speech by Gabriela (Flash 1) and Tiago (Flash 4).

The problem that arose in the flash refers to the hard times teachers face to realize goals, functions and ways to teach Mathematics contents in the classroom. In this sense, there is a huge loss both during planning and execution of the activities. This becomes clear when we look at Mathematics graduate programs in Brazil: different course guidelines depending on the institution; dichotomy between academic knowledge and didactic knowledge; precarious specific knowledge, didactics and theoretical-methodological teaching propositions. Libâneo (2008) also highlights the lack of organization about pedagogical activities and the lack of clarity about theoretical and conceptual milestones by teachers-educators.

The speeches by Luciana (Flash 2) and Tiago (Flash 4) are based on the concepts by Libâneo (2008), when he states that the prescriptive and instrumental didactics in most teacher education courses in Brazil are followed by traditional teaching methodologies. This goes in the opposite direction of the idea that teaching and learning are surrounded by a growing complexity, hence demanding other types of organization and relationships.

The flashes by Luciana and Tiago also rose the question highlighted by Libâneo (2008) about the often mismatch among teachers, managers, politicians and researchers regarding aims, functions and functioning of public schools in Brazil. It is quite unclear and there is minimal consensus about quality criteria of plan actions 
in the school system and in the teachers' education process. Such issue can be better understood by taking into account the impact of internationalization of education policies in developing and poor countries. Consistent studies (FRIGOTTO; CIAVATTA, 2003; SHIROMA; GARCIA; CAMPOS, 2011) show the growing influence of international organisms on Brazilian educational policies, which has a clear influence on content teaching, affecting schools and dynamics in classroom environment.

Such influence leads to the mediocre teaching of Mathematics contents based on a school substantiated by welcoming behaviors and social experiences, with clear intentions to harmonize social relationships. This is about combining teaching practices based on results to social protection, but it leads to a visible emptying of Mathematics contents. This policy results in schools that provide knowledge to rich students and social protection to the poor. And this is quite the situation in Brazil (LIBÂNEO, 2008), where issues such as teaching maintenance and content learning are not taken into account. "[...] Content is important not as facts to be memorized, [...] but because without it students cannot acquire concepts" (YOUNG, 2011, p. 614, our translation). Thus, human development only occurs through the appropriation of socio-cultural human experiences acquired through learning contents. Such learning process must take place under concrete material and social conditions that must mostly happen at school. But, to make it come true, this process called didactic process must be organized; it must allow the formative meeting between student and the content to be taught.

Marilene (Flash 3) and Tiago (Flash 4) encouraged the discussion about teachers' education, about the role of didactics in Mathematics teachers' learning process. According to Danilov (1978), didactics studies the teaching process according to which development opens room for a systematized knowledge. In other words, "[...] didactics must allow the convergence to the unity of the teaching/learning process" (DANILOV, 1978, p. 46, our translation). Thus, the object of study of didactics is neither the teaching process nor the learning process separately, but teaching and its intentions, such as learning. Despite the understanding about the learning process of undergraduate Mathematics teachers in training, they still show that significant antinomies do persist, as shown in the speech by Aline (Flash 5).

The educational process highlighted in this flash should assure unity between learning and teaching and their relationship with knowledge. It should be so in situations in which students are guided in their learning process by the teacher in order to appropriate the product of human experiences and to achieve development. It is necessary to point out that the appropriation process consists in the subjective re-elaboration of knowledge and in abilities and capacities socially acquired from socially developed cultural tools (school content). Therefore, "[...] appropriation results from the activity apprehended by the individual when he/she learns to dominate the socially developed method by dealing with the world of objects and to change this world, which often gradually becomes the means for activities characteristic of the individual" (DAVIDOV; MARKOVA, 1987, p. 5, our translation).

Authors such as Libâneo (2008) and Fiorentini (2009) highlight the duality between teaching and appropriation of most of Mathematics contents in Brazilian public schools. They also draw attention to the discrepancy between public and private schools in Brazil, since the private ones invest in Mathematics teaching, which 
becomes a structuring element for learning. On the other hand, most students in public schools are guided to the fulfilment of social and assistance subjects. Such fragmentation results in a lack of bond between basic didactics and discipline didactics or, yet, between didactic knowledge and specific knowledge in Mathematics licensures in Brazil. The perception about this fragmentation is clear in the speech by Vivian (Flash 6), who highlights the lack of understanding about the importance of pedagogical knowledge in courses in this field.

Overcoming this fragmentation mentioned by Vivian depends on acknowledging the social character of teaching, which brings along the intention to guide students' activities. With the objective, contents must be seen as a set of scientific knowledge about a given subject, in the present case, Mathematics. Therefore, they are socially and historically constituted, becoming a product from human social and historical experiences - considered essential to promote the subject-student's development. As stated by Davidov (1988, p. 172, our translation), "[...] the teaching process plays the main role in individuals' development, most of all, through the content about the knowledge to be appropriated". Still, according to Davidov (1988), contents are the means for the formation of human mental processes, and this is one of the reasons why didactics should be extremely valued in teachers' education processes.

If, by organizing Mathematics teaching, one does not understand the importance of the didactics process as capable of promoting the formative meeting between students and the content to be taught, the object of study of didactics is lost. This object encompasses peculiarities of the teaching and learning processes, which focus on organizing the contents according to teaching levels. In that direction, teaching Mathematics contents should mean using the abstract features of the general laws of a given content; which means, finding the concrete in all its complexity, assuming that such move is not possible when didactics is not taken into account for organization of teaching and, consequently, learning.

The logics behind the argument about the importance of content as an aspect composing the pedagogical activity of Mathematics teachers, as well as of the role of didactics in the establishment of a unity between teaching and learning, leads to the understanding that the Mathematics teachers' education system in Brazil needs to unite in the sense that the education process so that the inter-relationship is assured. Such search for unity implies acknowledging that the preservice education of these teachers needs to set more solid theoretical and practical bonds with didactics, so that it will be possible to break barriers between specific knowledge and didactical knowledge. Being aware of such fact is the main point in Yann's speech's (Flash 7).

Therefore, based on the indicatives of the comprehension process of seeing content as an element of the development of pedagogical activities, we analyzed how such process reduced the object to its abstract universal expression. The proposition to understand such abstract universal relations in a theoretical way means providing researchers with the conditions to rise from abstract to concrete. However, we are not saying that it is certain that acting this way - going from abstract to concrete means reproducing all the details found in the investigation, mainly because such question would bring along impossibilities. That is why each flash was used to help understanding the way that the thoughts of each participant had appropriated the contents as elements of their pedagogical activity. "[...] This investigation is not a 
systematic progression, as it is a complex and entangled movement, so it progresses non-linearly" (ILYENKOV, 2008, p. 165). This concept relies on the idea that a full description of a phenomenon is not seen in ordered and categorized stages, free from unexpected events and contradictions. Instead, it is covered by the idea of movement, which was kept in the analysis.

\section{Concluding Remarks}

During writing of this manuscript, we sought to build knowledge about how to understand Mathematics contents as elements to change the pedagogical activity of undergraduate teachers.

Thereby, this investigation focused on the pedagogical activity of Mathematics teachers, on understanding how teachers in training appropriated the Mathematics content as an element to change their pedagogical activity in such a fashion that it would go beyond the apparent development of an education process, in a way to consolidate as an essential trace for their pedagogical activity. This way, by organizing the formative experiment, we managed to create conditions for undergraduate teachers to face selection of contents, so that these would be addressed in their teaching activity as part of their pedagogical activity.

All methodological principles proposed for planning, re-elaboration and development of these tasks by the undergraduate Mathematics teachers express the theoretical perspective underlying the present philosophical approach, namely, teaching Mathematics contents in order to accomplish the omnilateral development of the individual to their maximal potential. It implies recurring to the human aspect, which means that the reference to promote development for the teacher-individual and the student-individual must be the higher possibilities of development historically generated by the human aspect.

\section{Acknowledgment}

We would like to thank Fundação de Amparo à Pesquisa do Estado de Goiás for financial support for the development of this research.

\section{References}

CEDRO, W. L. O motivo e a atividade de aprendizagem do professor de matemática: uma perspectiva histórico-cultural. Tese (Doutorado em Educação) - Faculdade de Educação, Universidade de São Paulo, São Paulo, 2008. DOI: https://doi.org/10.11606/T.48.2008.tde-17122009-080649.

D'AMBRÓSIO, U. Educação matemática: da teoria à prática. Campinas: Papirus, 2007.

DANILOV, M. A. Didáctica de la escuela media. La Habana: Editorial Pueblo y Educación, 1978.

DAVIDOV, V. La enseñanza escolar y el desarrollo psíquico. Moscú: Editorial Progreso, 1988.

DAVIDOV, V.; MARKOVA, A. K. La concepción de la actividad de estudio en los escolares. In: SHUARE, M. (org.). La psicologia evolutiva em la URSS: antologia. Moscú: Editorial Progreso, 1987. p. 324-341.

FIORENTINI, D. A pesquisa e as práticas de formação de professores de matemática em face às políticas públicas no Brasil. Bolema, Rio Claro, v. 21, n. 29, p.43-70, 2009. Retrieved Mar. 12, 2021 from: https://www.periodicos.rc.biblioteca.unesp.br/index.php/bolema/article/view/1718/. 
FRIGOTTO, G.; CIAVATTA, M. Educação básica no Brasil na década de 1990: subordinação ativa e consentida à lógica de mercado. Educação \& Sociedade, Campinas, v. 24, n. 82, p. 93-130, 2003.

GATTI, B. A.; NUNES, M. M. R. (org.). Formação de professores para o ensino fundamental: estudo de currículos das licenciaturas em pedagogia, língua portuguesa, matemática e ciências biológicas. São Paulo: FCC: DPE, 2009.

ILYENKOV, E. V. The dialectics of the abstract and the concrete in Marx's Capital. Delhi: Aakar Books, 2008.

KOSIK, K. Dialectics of the concrete: a study on problems of man and world. Boston: D. Reidel Publishing, 1969.

LANNER DE MOURA, A. R. Movimento conceitual em sala de aula. In: MIGUEIS, M. R.; AZEVEDO, M. G. (org.). Educação matemática na infância: abordagens e desafios. Serzedo, Portugal: Gailivro, 2007. p. 65-84.

LIBÂNEO, J. C. Didática e epistemologia: para além do embate entre a didática e as didáticas específicas. In: VEIGA, I. P. A.; D'ÁVILA, C. (org.). Profissão docente: novos sentidos, novas perspectivas. Campinas: Papirus, 2008. p. 112-130.

LIBÂNEO, J. C. A didática e a aprendizagem do pensar e do aprender: a teoria histórico cultural da atividade e as contribuições de Vasili Davydov. Revista Brasileira de Educação, Rio de Janeiro, n. 27, p. 5-24, 2004. DOI: https://doi.org/10.1590/S1413-24782004000300002.

LORENZATO, S. Para aprender matemática. 3. ed. Campinas: Autores Associados, 2010.

MORAES, S. P. G. Avaliação do processo de ensino e aprendizagem em matemática. 2008. Tese (Doutorado em Educação) - Faculdade de Educação, Universidade de São Paulo, São Paulo, 2008.

MOURA, M. O. Pesquisa colaborativa: um foco na ação formadora. In: BARBOSA, R. L. L. (org.). Trajetórias e perspectivas da formação de educadores. São Paulo: Editora UNESP, 2000. p. 36-44.

MOURA, M. O.; ARAUJO, E.; RIBEIRO, F.; PANOSSIAN, M. L.; MORETTI, V. D. A atividade orientadora de ensino como unidade entre ensino e aprendizagem. In: MOURA, M. O. (org.). A atividade pedagógica na teoria histórico-cultural. São Paulo: Loyola, 2016. p. 81-109.

PIMENTA, S. G.; LIMA, M. S. L. Estágio e docência. São Paulo: Cortez, 2017.

RADFORD, L. Cognição matemática: história, antropologia e epistemologia. São Paulo: Livraria da Física, 2011.

SHIROMA, E. O.; GARCIA, R. M. C.; CAMPOS, R. F. Conversão das "almas" pela liturgia da palavra: uma análise do discurso do movimento todos pela educação. In: HALL, S.; MAINARDES, J. (org.). Políticas educacionais: questões e dilemas. São Paulo: Cortez, 2011. p. 98-114.

SILVA, M. M. A apropriação dos aspectos constituintes da a tividade pedagógica por professores de matemática em formação inicial. 2018. Tese (Doutorado em Educação em Ciências e Matemática) - Universidade Federal de Goiá, Goiânia, 2018. Retrieved Mar. 12, 2021 from: http://repositorio.bc.ufg.br/tede/handle/tede/9002.

VIGOTSKI, L. S. Obras escogidas: tomo III. Madrid: Visor, 1995.

VIGOTSKI, L. S. Obras escogidas: tomo II. Madrid: Visor, 2001.

VIGOTSKI, L. S. Linguagem, desenvolvimento e aprendizagem. São Paulo: Ícone, 2003.

VIGOTSKI, L. S. Psicologia pedagógica. São Paulo: Martins Fontes, 2004.

YOUNG, M. F. D. O futuro da educação em uma sociedade do conhecimento: o argumento radical em defesa de um currículo centrado em disciplinas. Revista Brasileira de Educação, Rio de Janeiro, v. 16, p. 609-625, 2011. DOI: https://doi.org/10.1590/S1413-24782011000300005. 